Article

\title{
Cytotoxicity, Fractionation and Dereplication of Extracts of the Dinoflagellate Vulcanodinium rugosum, a Producer of Pinnatoxin G
}

\author{
Marie Geiger ${ }^{1,2, \dagger}$, Gwenaëlle Desanglois ${ }^{3, \dagger}$, Kevin Hogeveen ${ }^{3}$, Valérie Fessard ${ }^{3}$, \\ Thomas Leprêtre $^{1,2}$, Florence Mondeguer ${ }^{1}$, Yann Guitton ${ }^{1,2}$, Fabienne Hervé ${ }^{1}$, \\ Véronique Séchet ${ }^{1}$, Olivier Grovel ${ }^{2}$, Yves-François Pouchus ${ }^{2}$ and Philipp Hess ${ }^{1}$ * \\ 1 Ifremer, Laboratoire Phycotoxines, Centre Atlantique, 44311 Nantes Cedex, France; \\ E-Mails: marie.geiger@hotmail.fr (M.G.); thomaslepretre@hotmail.com (T.L.); \\ florence.mondeguer@ifremer.fr (F.M.); yann.guitton@univ-nantes.fr (Y.G.); \\ fabienne.herve@ifremer.fr (F.H.); veronique.sechet@ifremer.fr (V.S.)
}

2 MMS EA2160, Faculté de Pharmacie, LUNAM, Université de Nantes, 44035 Nantes, France; E-Mails: olivier.grovel@univ-nantes.fr (O.G.); yves-francois.pouchus@univ-nantes.fr (Y.-F.P.)

3 Unité de Toxicologie des Contaminants, ANSES, 35302 Fougères, France; E-Mails: gwenaelle.desanglois@anses.fr (G.D.); kevin.hogeveen@ anses.fr (K.H.); valerie.fessard@anses.fr (V.F.)

$\dagger$ These authors contributed equally to this work.

* Author to whom correspondence should be addressed; E-Mail: philipp.hess @ifremer.fr; Tel.: +33-240-374-257; Fax: +33-240-374-267.

Received: 5 June 2013; in revised form: 18 July 2013 / Accepted: 7 August 2013 /

Published: 2 September 2013

\begin{abstract}
Pinnatoxin G (PnTX-G) is a marine toxin belonging to the class of cyclic imines and produced by the dinoflagellate Vulcanodinium rugosum. In spite of its strong toxicity to mice, leading to the classification of pinnatoxins into the class of "fast-acting toxins", its hazard for human health has never been demonstrated. In this study, crude extracts of $V$. rugosum exhibited significant cytotoxicity against Neuro2A and $\mathrm{KB}$ cells. $\mathrm{IC}_{50}$ values of $0.38 \mu \mathrm{g} \mathrm{mL}^{-1}$ and $0.19 \mu \mathrm{g} \mathrm{mL}^{-1}$ were estimated on Neuro2A cells after only $24 \mathrm{~h}$ of incubation and on $\mathrm{KB}$ cells after $72 \mathrm{~h}$ of incubation, respectively. In the case of Caco-2 cells $48 \mathrm{~h}$ after exposure, the crude extract of $V$. rugosum induced cell cycle arrest accompanied by a dramatic increase in double strand DNA breaks, although only $40 \%$ cytotoxicity was observed at the highest concentration tested $\left(5 \mu \mathrm{g} \mathrm{mL}{ }^{-1}\right)$. However,
\end{abstract}


PnTX-G was not a potent cytotoxic compound as no reduction of the cell viability was observed on the different cell lines. Moreover, no effects on the cell cycle or DNA damage were observed following treatment of undifferentiated Caco-2 cells with PnTX-G. The crude extract of $V$. rugosum was thus partially purified using liquid-liquid partitioning and SPE clean-up. In vitro assays revealed strong activity of some fractions containing no PnTX-G. The crude extract and the most potent fraction were evaluated using full scan and tandem high resolution mass spectrometry. The dereplication revealed the presence of a major compound that could be putatively annotated as nakijiquinone $\mathrm{A}$, $N$-carboxy-methyl-smenospongine or stachybotrin A, using the MarinLit ${ }^{\mathrm{TM}}$ database. Further investigations will be necessary to confirm the identity of the compounds responsible for the cytotoxicity and genotoxicity of the extracts of V. rugosum.

Keywords: dereplication; cyclic imine; HRMS; bioactivity; pinnatoxins

\section{Introduction}

Shellfish belonging to the genus Pinna had first been implicated in food poisoning in China in 1990 [1]. Pinnatoxin A (PnTX-A) was the first analogue described [2] (Figure 1), followed by PnTX-B, -C and -D, all isolated from viscera of Pinna muricata originated from Okinawa, Japan [3,4]. PnTX-E, -F and -G were discovered in oysters coming from Australia and New-Zealand, and PnTX-F and $-\mathrm{G}$, which are algal metabolites, are suspected to be the metabolic precursor of all known PnTXs [5]. In Europe, PnTXs were first identified in Norway in 2011 in mussels and seawater samples [6].

In the regions affected by these contaminations, different dinoflagellate producers of PnTXs have been isolated: one organism was identified as a producer of PnTX-E and -F in New-Zealand [7], one as a producer of PnTX-G in Japan [8] and another one producing PnTX-E, -F and -G in Australia [9]. In 2011, a new species belonging to a new benthic dinoflagellate genus was isolated from a French Mediterranean lagoon (Ingril), and has been named Vulcanodinium rugosum [10]. This isolate has been shown to produce PnTX-G [11]. By morphological and phylogenetic comparison with the isolates from Japan, New-Zealand and Australia, V. rugosum has been identified as a single species producing PnTX-E, -F and $-\mathrm{G}$ in these regions [12]. More recently, PnTX-A and $-\mathrm{G}$ have been identified in mussels in Canada, with the first description of PnTX-G fatty acids esters [13].

To date, no acute human intoxication by consumption of shellfish contaminated by PnTXs has been reported, explaining the current absence of a regulation of PnTXs in Europe. However, a recent risk evaluation on cyclic imines suggested that further information is required on toxicology and distribution of these compounds [14]. Indeed, PnTXs and more generally, cyclic imines, have been demonstrated to be fast acting toxins on mammalian models. These toxins exhibit acute toxicity, with neurological symptoms appearing in an "all or nothing" manner [15]. Following intra-peritoneal (i.p.) injection into mice, PnTX-E exhibited an $\mathrm{LD}_{50}$ of between 16 and $57 \mu \mathrm{g} \mathrm{kg}^{-1}$, PnTX-F an $\mathrm{LD}_{50}$ of between 12.7 and $45 \mu \mathrm{g} \mathrm{kg}^{-1}$, and PnTX-G an $\mathrm{LD}_{50}$ of between 48 and $50 \mu \mathrm{g} \mathrm{kg}^{-1}$ [5,16]. At a lethal dose, these three analogues induced hyperactivity in mice during the first 10 min following the i.p. injection, then a strong decrease of the respiratory rate, followed by death of the animals 
between 30 and 50 min [5,16]. In comparison to other cyclic imines, PnTX-F and $-\mathrm{G}$ exhibited high oral toxicity in mice, with $\mathrm{LD}_{50}$ s of 25 and $150 \mu \mathrm{g} \mathrm{kg}^{-1}$, respectively. This observation is likely to be correlated with the high hydrolytic stability of pinnatoxins at different $\mathrm{pH}$ in aqueous media [17], and suggested a high absorption of these toxins from the gastro-intestinal (GI) tract in mice [16].

Figure 1. Structures of Pinnatoxin A (PnTX-A) and -G (PnTX-G). PnTX-A is a shellfish metabolite of the algal PnTX-G, with the double bond in the side chain oxidised to form a carboxylic acid group. PnTXs also contain a cyclic imine functional group.

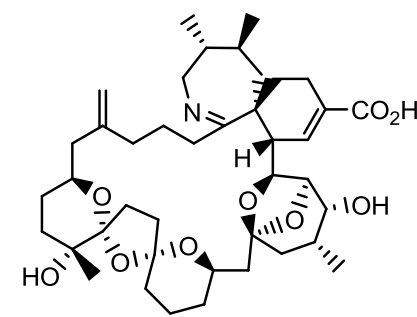

Pinnatoxin A

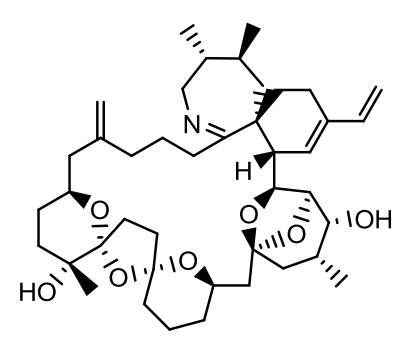

Pinnatoxin G

Concerning in vitro activities, only PnTX-D has been reported to exhibit cytotoxicity on the P388 leukemia cell line [18]. Initially, it has been suggested that the mechanism of action of PnTXs was an activation of calcium channels [1]. However, this hypothesis has never been confirmed to our knowledge. PnTX-A, -E, $-\mathrm{F}$ and $-\mathrm{G}$ were then reported to block the nicotinic receptors of acetylcholine, with a major role of the spiro-imine subunit in this activity $[19,20]$.

In this context, in order to investigate the various mechanisms of action and the extent of toxicity of PnTXs, the present work aimed at studying the in vitro toxicity of PnTX-G and V. rugosum extracts using cytotoxicity assays, investigating the DNA damage and effects on the cell cycle and trying to pinpoint bioactive compounds other than PnTX-G.

\section{Results}

\subsection{Toxin Content of V. rugosum and Purification of PnTX-G}

Axenic cultures of $V$. rugosum (276 mg pellet) yielded $22 \mathrm{mg}$ of dried crude extract containing $10.5 \mu \mathrm{g}$ of PnTX-G. The content of PnTX-G in this axenic biomass was somewhat less but of a similar height of order as the average over ten batches of non-axenic cultures in our laboratory (data not shown). The biomass of $V$. rugosum used for the fractionation and the toxicological evaluation had not been grown under axenic conditions as it is extremely difficult to maintain pilot-scale cultures in such conditions.

The fractionation scheme, which followed the isolation scheme as published by Selwood et al., 2010 [5], allowed for separation of PnTX-G from other matrix components as PnTX-G was 40 times purer in fraction 3 of the silica fractionation step than in the crude extract, even when accounting for loss of toxin (Table 1). PnTX-G quantitatively partitioned into the DCM and the aqueous methanol (aqueous $\mathrm{MeOH}$ ) phases in the first and second partitioning steps, respectively; the main cytotoxic 
components also were found in these two phases and not in the aqueous and hexane phases (data not shown). Also, fraction 2 only contained a negligible trace of PnTX-G compared to fraction 3.

Table 1. Fractionation of crude extract used for toxicological assessment of V. rugosum. Approximately $99 \%$ and $96 \%$ of PnTX were recovered in DCM and aqueous $\mathrm{MeOH}$ phases during the first and second partitioning, respectively. More than 99\% of PnTX-G was recovered in fraction 3 of the silica solid phase extraction (SPE) step.

\begin{tabular}{cccc}
\hline & Fraction & Sample mass & PnTX-G \\
\cline { 3 - 4 } Crude extract & n/a & 2050 & $(\boldsymbol{\mu g})$ \\
& DCM phase & 442 & 844 \\
Partitioning 1 & Aqueous phase & 1618 & 620 \\
& Interface & 168 & 0.80 \\
Partitioning 2 & Aq. MeOH phase & 168 & 5.80 \\
& Hexane phase & 274 & 571 \\
& F1 & 7.00 & 21.2 \\
Fractions & F2 & 73.1 & 0.00 \\
& F3 & 38.8 & 0.05 \\
& F4 & 6.10 & 649 \\
& F5 & 21.7 & 0.27 \\
& & & 0.16 \\
\hline
\end{tabular}

\subsection{In Vitro Toxic Effects of Crude and Partitioned Extracts of Vulcanodinium rugosum}

The incubation times of $V$. rugosum crude extract varied according to the cell line. Undifferentiated Caco-2 cells were incubated for 24 or 48 h. For Neuro2A and differentiated Caco-2 cells, incubation was 24 and $48 \mathrm{~h}$, respectively. KB cells were incubated for 24,48 or $72 \mathrm{~h}$.

The crude extract of $V$. rugosum induced a concentration-dependent reduction of the cell viability of Neuro2A cells after only $24 \mathrm{~h}$ with an $\mathrm{IC}_{50}$ of $0.38(0.24-0.51) \mu \mathrm{g} \mathrm{mL}^{-1}$ (Figure 2a). The same extract only slightly affected the viability of undifferentiated Caco 2 cells, independent of exposure duration ( 24 or $48 \mathrm{~h}$ ). For both exposure durations, no $\mathrm{IC}_{50}$ could be determined, even though a $40 \%$ cytotoxicity was observed at the highest concentration tested $\left(5 \mu \mathrm{g} \mathrm{mL}^{-1}\right)$, (Figure $2 \mathrm{~b}$ ). Moreover, no cytotoxicity was observed on differentiated Caco- 2 cells after $48 \mathrm{~h}$ of incubation (data not shown). The crude extract of $V$. rugosum induced a time- and concentration-dependent reduction of the cell viability of $\mathrm{KB}$ cells (Figure $2 \mathrm{c}$ ). The $\mathrm{LD}_{50} \mathrm{~s}$ (with confidence interval at 95\%) of $V$. rugosum crude extract on KB cells were 9 (7.8-10.2), $1(1.09-0.91)$ and $0.19(0.26-0.12) \mu \mathrm{gL}^{-1}$ after 24,48 and $72 \mathrm{~h}$ of incubation, respectively. The extract was more potent on $\mathrm{KB}$ cells than on undifferentiated Caco- 2 cells, and even more potent on Neuro2A cells.

The cytotoxic activities were monitored along the partitioning steps of the crude extract of V. rugosum. Cytotoxicity was higher in both the DCM and the aqueous $\mathrm{MeOH}$ fractions than in the crude extract, both when using Neuro2A and KB cells (Table 2). However, as with the crude extract, no $\mathrm{IC}_{50}$ could be calculated for those two fractions on undifferentiated (Table 2) and differentiated (data not shown) Caco-2 cells, as only 40\%-45\% cytotoxicity was reached in undifferentiated Caco- 2 cells for the highest concentrations tested $\left(5 \mu \mathrm{g} \mathrm{mL}^{-1}\right)$. 
Figure 2. Effect of a crude extract of $V$. rugosum on Neuro2a cells (a), undifferentiated Caco- 2 cells (b), and KB cells (c). Different exposure times were evaluated for the crude extract: $24 \mathrm{~h}$ for Neuro2A, 24 and $48 \mathrm{~h}$ for undifferentiated Caco-2 and 24, 48 and $72 \mathrm{~h}$ for KB cells. Data presented (mean \pm SEM) were obtained from two independent experiments (duplicate wells per experiment for Neuro2A and Caco-2, triplicate wells per experiment for KB cells).
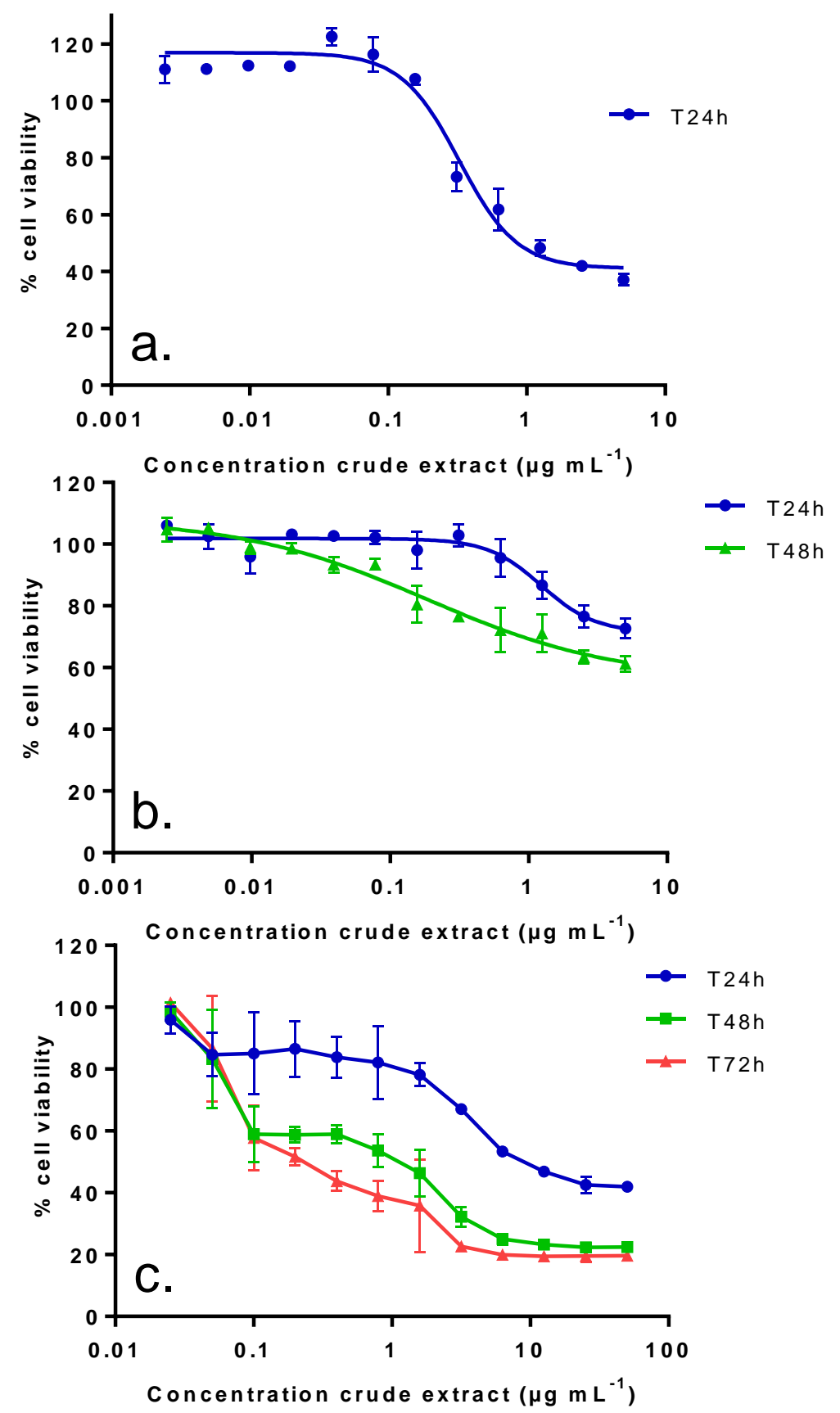
Table 2. Cytotoxicity $\mathrm{IC}_{50}$ values $\left(\mu \mathrm{g} \mathrm{mL}{ }^{-1}\right)$ for the crude extract, $\mathrm{DCM}$ and aq.MeOH fractions of $V$. rugosum crude extract $(N=2)$.

\begin{tabular}{|c|c|c|c|}
\hline \multicolumn{4}{|c|}{$\mathrm{IC}_{50}\left(\mu \mathrm{g} \mathrm{mL} \mathrm{L}^{-1}\right)$ : median (values obtained with two independent experiments) } \\
\hline & Neuro2A cells & & Undifferentiated Caco-2 cells \\
\hline & $(24 \mathrm{~h}$ of & (72 $\mathrm{h}$ of incubation) & $(48 \mathrm{~h} \mathrm{o}$ \\
\hline Crude extract & $0.38(0.24-0.51)$ & $0.19(0.26-0.12)$ & N.R. $(40 \%)$ \\
\hline DCM fraction & $0.15(0.14-0.15)$ & $0.007(0.006-0.008)$ & N.R. $(40 \%)$ \\
\hline aq.MeOH fraction & $0.03(0.01-0.04)$ & $0.004(0.003-0.004)$ & N.R. $(45 \%)$ \\
\hline
\end{tabular}

N.R.: no $\mathrm{IC}_{50}$ was observed and maximum cytotoxicity at $5 \mu \mathrm{g} \mathrm{mL}^{-1}$ indicated in brackets.

Ki-67 was measured as a biomarker of cell proliferation, typically present at specific phases of the cell cycle. Although the crude extract of V. rugosum had little effect on Caco-2 viability, there was a significant, dose-dependent increase in Ki-67 positive cells. This effect was even more pronounced for the partially purified aqueous $\mathrm{MeOH}$ fraction, where a maximum effect was already observed at the lowest dose level. The distinct punctate pattern of Ki-67 immunofluorescence in cells treated with the crude extract is indicative of a cell cycle arrest in the G1/S phase. This cell cycle arrest was accompanied by a dramatic increase in $\gamma \mathrm{H} 2 \mathrm{AX}$ immunofluorescence at mid-range concentrations of crude $V$. rugosum extract and even at the lowest range of the partially purified extract, i.e., in the aqueous $\mathrm{MeOH}$-fraction (Figure 3a,b).

\subsection{In Vitro Effects of Various Fractions of V. rugosum Extract}

The cytotoxic activities were monitored along the fractionation process on the three different cell lines.

Five fractions were obtained after fractionation of the aqueous $\mathrm{MeOH}$ fraction of the $V$. rugosum extract. Among these fractions, fraction 3 was the only one containing a significant amount of PnTX-G (Table 1). A similar classification of the potency of these fractions according to their $\mathrm{IC}_{50}$ was obtained from Neuro2A and KB cells results, as follows: F2 > F3 > F4 > F5 > F1 (Table 3). The most potent fraction-fraction 2-exhibited an $\mathrm{IC}_{50}$ of $11(5-17)$ and $0.21(0.18-0.24) \mathrm{ng} \mathrm{mL}^{-1}$ on Neuro2A and $\mathrm{KB}$ cells, respectively. However, this fraction did not contain PnTX-G. The only fraction containing PnTX-G, fraction 3, showed $\mathrm{IC}_{50}$ of 25 and $2.59 \mathrm{ng} \mathrm{mL}^{-1}$ on Neuro2A and KB cells, respectively. On undifferentiated Caco-2 cells, no $\mathrm{IC}_{50}$ could be determined for any fraction: cytotoxicity increased by ca. $40 \%$ except for fraction 4 (25\% cytotoxicity), Table 3.

\subsection{In Vitro Effects of Pinnatoxin G}

In order to determine whether PnTX-G could contribute to the cytotoxicity observed with the crude extract, the pure toxin was tested on the different cell lines. Surprisingly, no cytotoxicity was induced in either Neuro2A cells ( $24 \mathrm{~h}$ exposure) or in undifferentiated Caco- 2 cells ( $48 \mathrm{~h}$ exposure) following exposure to PnTX-G up to $32 \mathrm{ng} \mathrm{mL}^{-1}$ (Figure $4 \mathrm{a}, \mathrm{b}$ ). Similarly, cell viability of differentiated Caco-2 was not affected by PnTX-G up to $32 \mathrm{ng} \mathrm{mL}^{-1}$ (data not shown). In KB cells, higher concentrations up to $400 \mathrm{ng} \mathrm{mL}^{-1}$ were tested, however, only slight reductions in $\mathrm{KB}$ cell viability (27\%) were observed 
following $72 \mathrm{~h}$ of treatment (Figure 4c). In addition, PnTX-G had no effect on either cell cycle progression or DNA damage in undifferentiated Caco-2 cells (Figure 3a,b).

Figure 3. Effect of crude extract of $V$. rugosum, the aqueous methanol fraction and PnTX-G on (a) Ki-67 expression and on (b) $\gamma \mathrm{H} 2 \mathrm{AX}$ phosphorylation in Caco- 2 cells. Data are presented as the mean average nuclear intensity of $\mathrm{Ki}-67$ and $\gamma \mathrm{H} 2 \mathrm{AX}$ immunofluorescence \pm SEM.
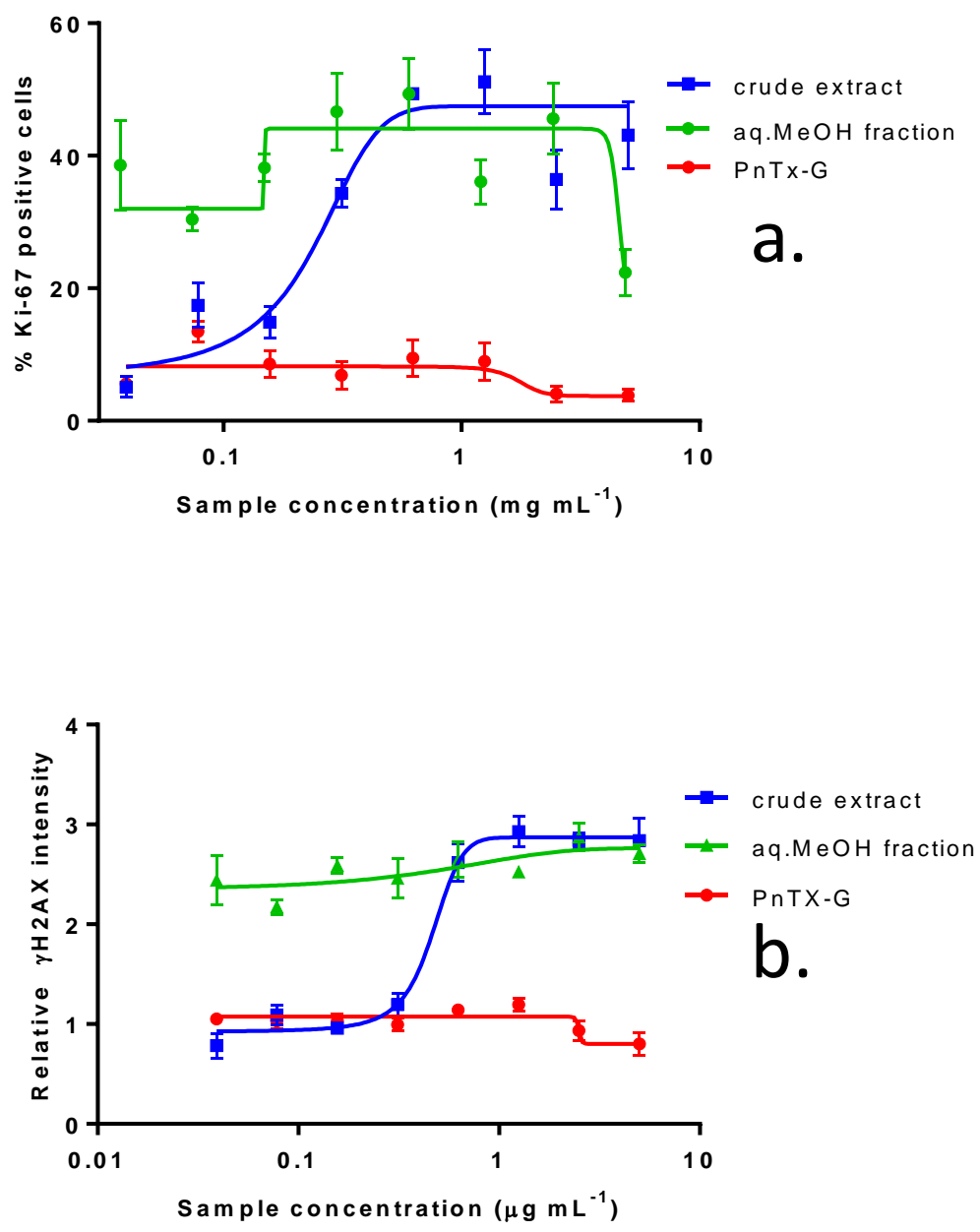

Table 3. Cytotoxicity $\mathrm{IC}_{50}$ values $\left(\mathrm{ng} \mathrm{mL}^{-1}\right)$ for the 5 fractions obtained using $\mathrm{SPE}$ cartridge $(N=2)$.

\begin{tabular}{|c|c|c|c|c|c|}
\hline \multicolumn{6}{|c|}{$\mathrm{IC}_{50}\left(\mathrm{ng} \mathrm{mL} \mathrm{L}^{-1}\right)$ : median (values obtained with two independent experiments) } \\
\hline & Fraction & Distribution & $\mathrm{KB}$ cells & Neuro2A cells & Undifferentiated Caco- 2 cells \\
\hline & Weight $(\%)$ & of PnTX-G (\%) & ( $72 \mathrm{~h}$ of incubation) & ( $24 \mathrm{~h}$ of incubation) & (48 h of incubation) \\
\hline F1 & 4.9 & 0 & $1023(958,1088)$ & N.R. $(45 \%)$ & N.R. $(44.5 \%)$ \\
\hline F2 & 50.3 & 0 & $0.21(0.18,0.24)$ & $11(5-17)$ & N.R. $(41.6 \%)$ \\
\hline F3 & 26.5 & 100 & $2.59(2.55,2.63)$ & $25(44-6)$ & N.R. $(42.6 \%)$ \\
\hline F4 & 4.6 & 0 & $53.6(45.4,61.8)$ & $575(760-390)$ & N.R. $(25.2 \%)$ \\
\hline F5 & 13.8 & 0 & $62.7(55.9,69.5)$ & $1140(800-1480)$ & N.R. $(41.1 \%)$ \\
\hline
\end{tabular}

N.R.: no $\mathrm{IC}_{50}$ was observed and maximum cytotoxicity at $5 \mu \mathrm{g} \mathrm{mL}^{-1}$ indicated in brackets. 
Figure 4. Effect of PnTX-G on Neuro2a cells (a), undifferentiated Caco-2 cells (b), and $\mathrm{KB}$ cells $(\mathbf{c})$. The effect was evaluated at a single time exposure: $24 \mathrm{~h}$ for Neuro2A, $48 \mathrm{~h}$ for undifferentiated Caco-2 and $72 \mathrm{~h}$ for $\mathrm{KB}$ cells. Data presented (mean $\pm \mathrm{SEM}$, in graph c, some error bars are smaller than the symbol of the data point) were obtained from two independent experiments (duplicate wells per experiment for Neuro2A and Caco-2, triplicate wells per experiment for KB cells).
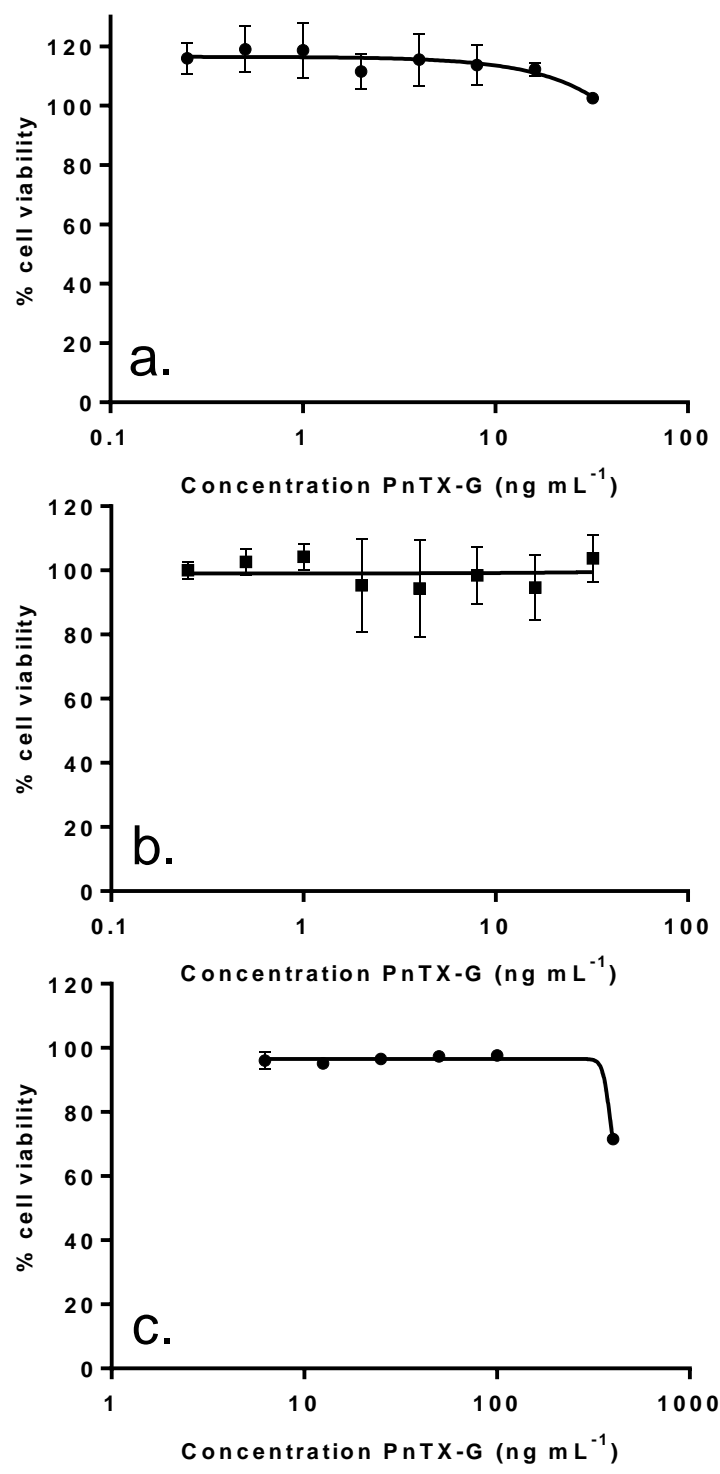

In undifferentiated Caco- 2 cells, the percentage of Ki-67 positive cells rose dramatically following treatment with purified fractions. This effect was primarily due to an increase in cells demonstrating a distinct punctate nuclear immunostaining, indicative of G1/S cell cycle arrest. Even though the fractions did not induce a large cytotoxicity in Caco-2 cells, in agreement with the cytotoxicity observed in Neuro2A and KB cells, fraction 2 had the greatest effect in promoting cell cycle arrest, followed by F3, F4, F5 and F1 (Figures 5a and 6a,b). The increase in $\gamma \mathrm{H} 2 \mathrm{AX}$ immunofluorescence was closely associated with the cell cycle arrest, although appearing at higher concentrations of the purified fractions (Figures $5 \mathrm{~b}$ and $6 \mathrm{c}, \mathrm{d}$ ). 
Figure 5. Effect of purified fractions of $V$. rugosum on Ki-67 expression (a) and on $\gamma \mathrm{H} 2 \mathrm{AX}$ phosphorylation (b) in Caco-2 cells. Data are presented as the mean average nuclear intensity of Ki-67 and $\gamma \mathrm{H} 2 \mathrm{AX}$ immunofluorescence \pm SEM.
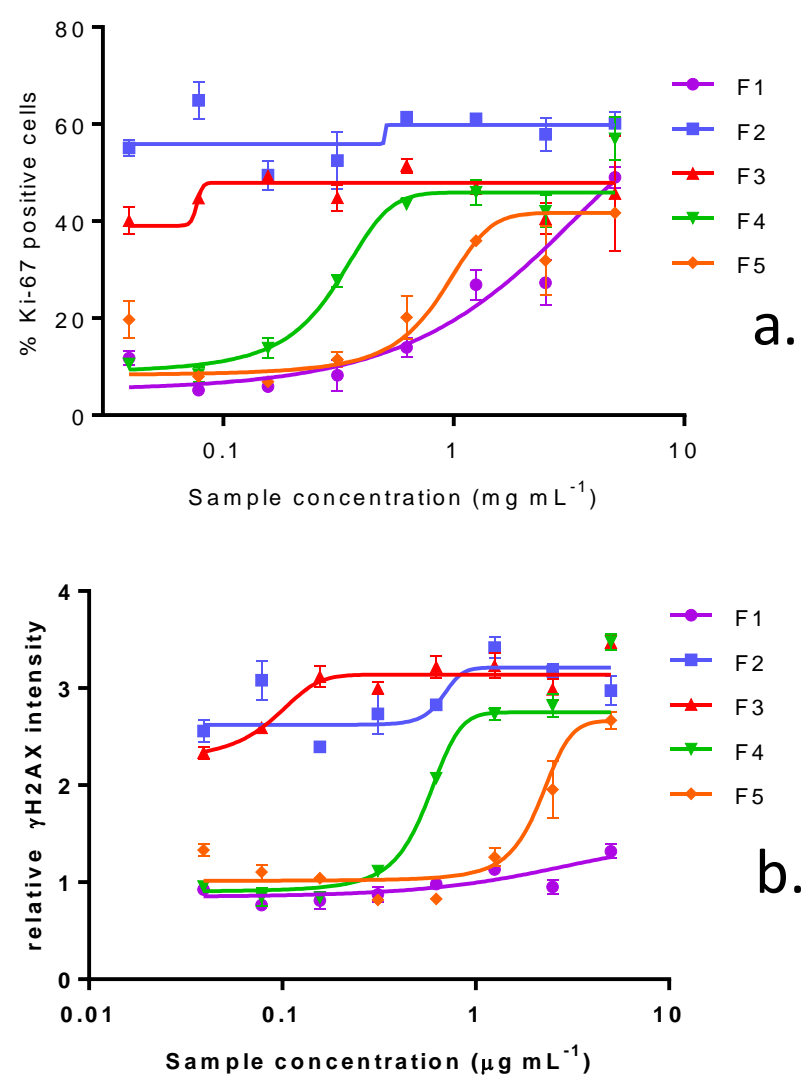

Figure 6. Representative images of (a) $\gamma \mathrm{H} 2 \mathrm{AX}$ immunofluorescence in untreated Caco-2 cells; (b) Caco-2 cells treated with F3 at $156 \mathrm{ng} \mathrm{mL}^{-1}$; (c) Ki-67 immunofluorescence in untreated Caco-2 cells; (d) Caco-2 cells treated with F3 at $156 \mathrm{ng} \mathrm{mL}{ }^{-1}$.
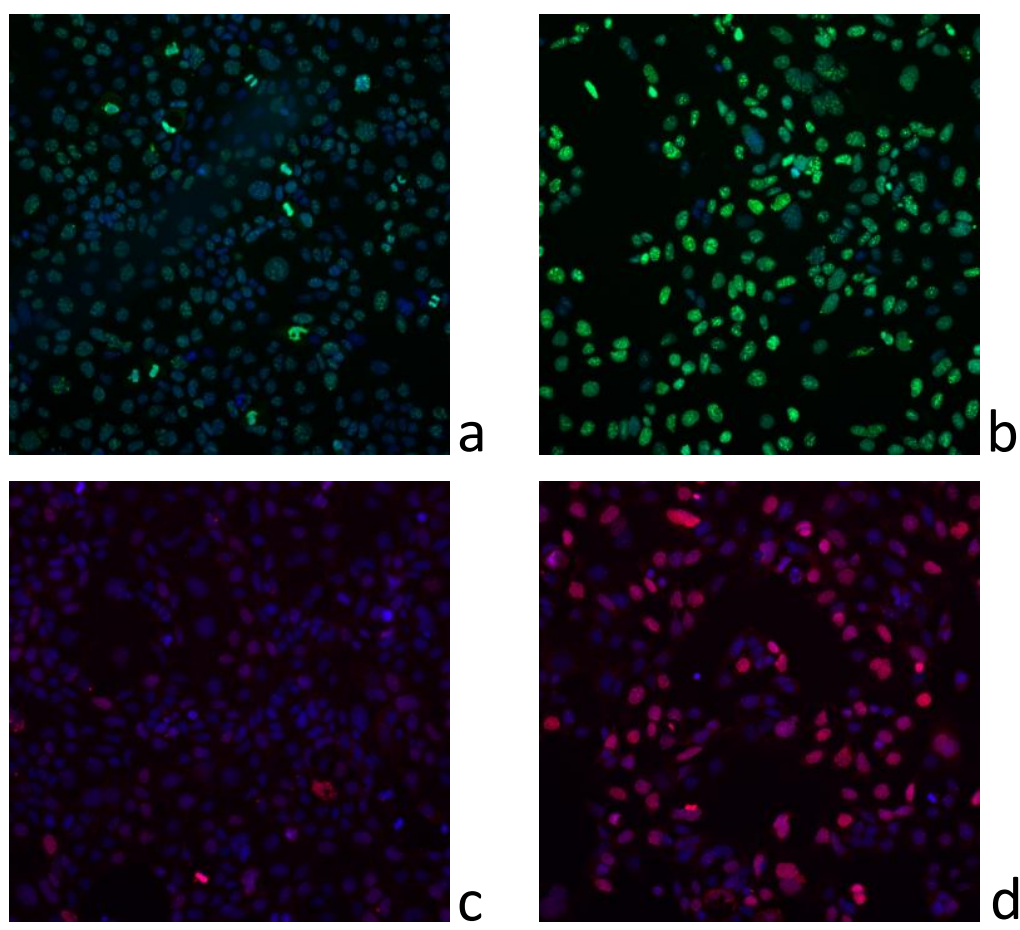


\subsection{Dereplication Study}

The chemical profile of the crude extract obtained from an axenic culture of $V$. rugosum was investigated using high resolution mass spectrometry in full scan mode. Analyses were carried out in triplicate, and the peaks obtained in the three experiments were dereplicated. PnTX-G could be confirmed on the basis of the retention time, fragmentation and the $m / z$ using an in-house database of our laboratory. For dereplication of unknowns, Agilent Mass Hunter software was used to calculate scores which are based both on the closeness of the measured $\mathrm{m} / \mathrm{z}$-value to the theoretical value $(\Delta \mathrm{ppm})$ in a database and on the isotope distribution. Thus, compounds with identical molecular formulas (isobaric compounds) have the same scores. Using the MarinLit ${ }^{\mathrm{TM}}$ [21] database, which does not contain retention time information, the most abundant compound (peak F) gave three hits for isobaric compounds: nakijiquinone $\mathrm{A}, N$-carboxy-methyl-smenospongine or stachybotrin $\mathrm{A}$, with a very good score of 99.4 (Figure $7 \mathrm{a}$ and Table 4). In Table 4, the abundance of each peak was relative to the abundance of the major peak, compound F. Five other compounds could be putatively annotated; however, several major compounds remained unidentified.

Figure 7. Compounds identified (using the Molecular-Feature-Extraction algorithm of the Mass Hunter software) (a) in a crude extract of an axenic culture of V. rugosum; (b) the F2 fraction obtained from a non-axenic culture of $V$. rugosum. The peak identification is detailed in Table 4.
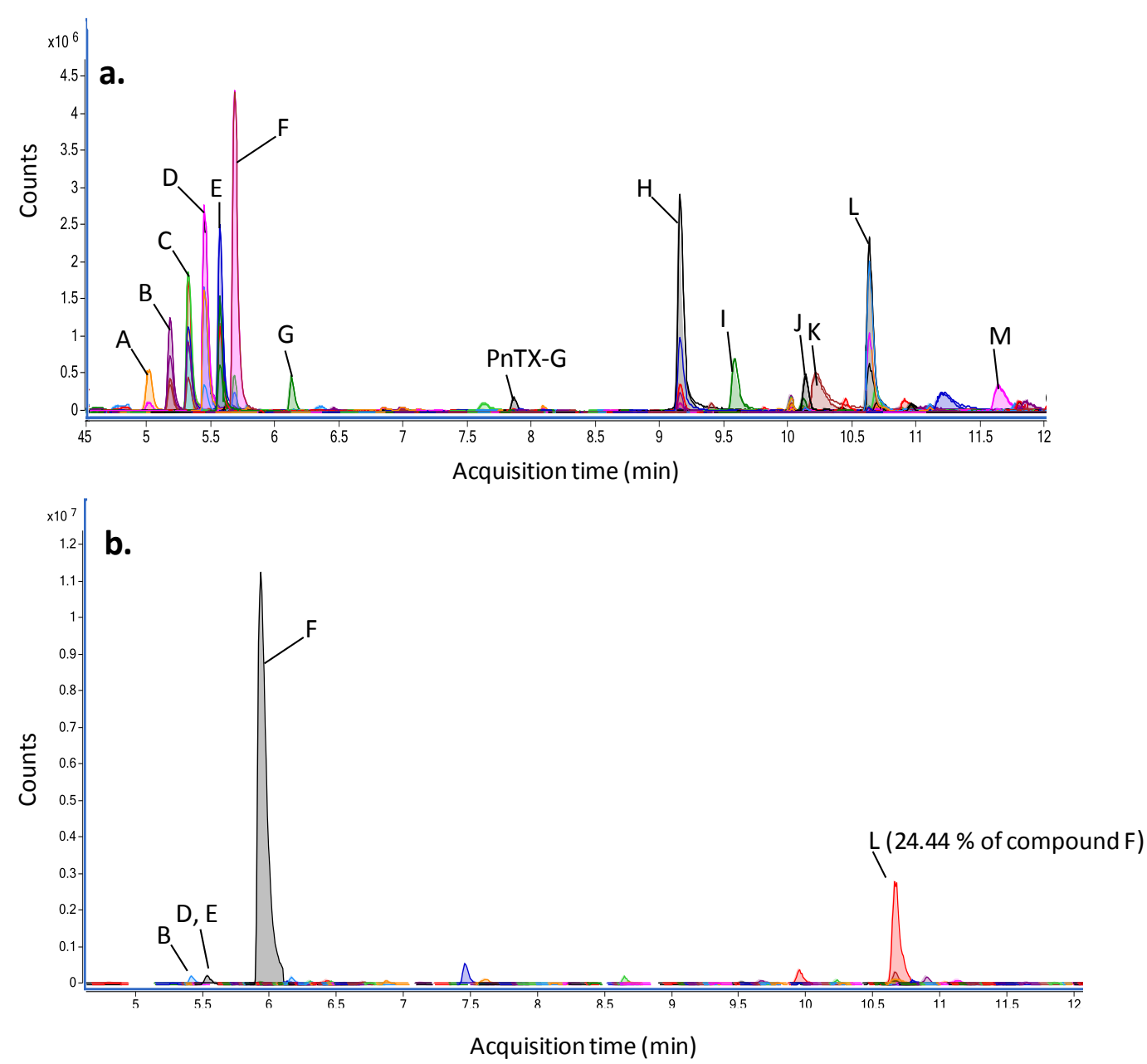
Table 4. Putative annotation of peaks observed on a chromatogram of an axenic V. rugosum crude extract, using the MarinLit ${ }^{\mathrm{TM}}$ database (SD = standard deviation).

\begin{tabular}{|c|c|c|c|c|c|c|c|c|c|}
\hline \multirow[t]{2}{*}{ Peak } & \multicolumn{2}{|c|}{ Experimental $m / z[\mathrm{M}+\mathbf{H}]^{+}$} & \multicolumn{2}{|c|}{$\begin{array}{l}\text { Relative abundance } \\
\text { of compound } F(\%)\end{array}$} & \multirow[t]{2}{*}{ Putative annotation using MarinLit database } & \multicolumn{2}{|l|}{ Score (DB) } & \multicolumn{2}{|l|}{ Diff (DB, ppm) } \\
\hline & Mean $(N=3)$ & SD & Mean $(N=3)$ & SD & & $\operatorname{Mean}(N=3)$ & SD & $\operatorname{Mean}(N=3)$ & SD \\
\hline $\mathbf{A}$ & 393.2102 & 0.0001 & 16.74 & 0.72 & unknown & - & - & - & - \\
\hline \multirow{2}{*}{ B } & 437.2362 & 0.0002 & 26.65 & 0.62 & unknown & - & - & - & - \\
\hline & 432.2810 & 0.0002 & 9.97 & 0.47 & unknown & - & - & - & - \\
\hline \multirow{2}{*}{$\mathbf{C}$} & 481.2622 & 0.0001 & 38.61 & 1.04 & unknown & - & - & - & - \\
\hline & 476.3067 & 0.0001 & 18.21 & 1.49 & unknown & - & - & - & - \\
\hline \multirow{2}{*}{ D } & 520.3331 & 0.0002 & 33.91 & 0.50 & unknown & - & - & - & - \\
\hline & 525.2886 & 0.0002 & 59.92 & 0.90 & unknown & - & - & - & - \\
\hline \multirow{3}{*}{$\mathbf{E}$} & 564.3593 & 0.0001 & 36.13 & 3.03 & unknown & - & - & - & - \\
\hline & 569.3147 & 0.0001 & 59.10 & 5.14 & unknown & - & - & - & - \\
\hline & 613.3408 & 0.0003 & 13.70 & 5.11 & unknown & - & - & - & - \\
\hline \multirow{3}{*}{$\mathbf{F}$} & \multirow{3}{*}{402.2281} & \multirow{3}{*}{0.0003} & \multirow{3}{*}{100.00} & \multirow{3}{*}{100.00} & Nakijiquinone A & \multirow{3}{*}{98.14} & \multirow{3}{*}{1.34} & \multirow{3}{*}{-1.38} & \multirow{3}{*}{0.56} \\
\hline & & & & & $N$-carboxy-methyl-smenospongine & & & & \\
\hline & & & & & Stachybotrin & & & & \\
\hline G & 370.2748 & 0.0000 & 10.83 & 0.23 & $N$-methyl-xestamine $\mathrm{D}$ & 99.44 & 0.03 & -0.84 & 0.02 \\
\hline PnTX-G & 694.4664 & 0.0003 & 1.06 & 0.06 & - & - & - & - & - \\
\hline \multirow{2}{*}{$\mathbf{H}$} & 343.2958 & 0.0001 & 66.03 & 1.95 & unknown & - & - & - & - \\
\hline & 240.2327 & 0.0001 & 8.74 & 0.50 & 2-hydroxypentadecanoic acid & 98.13 & 0.44 & -1.60 & 0.34 \\
\hline $\mathbf{I}$ & 272.2589 & 0.0001 & 20.50 & 0.70 & 2-amino-1,3,4-hexadecanetriol; $(2 S, 3 R, 4 R)$-form & 99.11 & 0.21 & -1.18 & 0.14 \\
\hline $\mathbf{J}$ & 692.3843 & 0.0003 & 4.04 & 0.38 & unknown & - & - & - & - \\
\hline $\mathbf{K}$ & 286.1444 & 0.0002 & 11.69 & 0.80 & Solanapyrone B; 7ct-Hydroxy, 4'-demethoxy, 4'-amino, 1-aldehyde & 99.03 & 0.71 & -1.12 & 0.53 \\
\hline \multirow{4}{*}{$\mathbf{L}$} & \multirow{3}{*}{453.1680} & \multirow{3}{*}{0.0001} & \multirow{3}{*}{61.23} & \multirow{3}{*}{0.14} & 7,11-dihydroxy-16-oxo-12-spongien-17-al; (713,1113)-form, Di-Ac & \multirow{3}{*}{97.96} & \multirow{3}{*}{0.94} & \multirow{3}{*}{-1.44} & \multirow{3}{*}{0.36} \\
\hline & & & & & Furcellataepoxylactone & & & & \\
\hline & & & & & Branacenal & & & & \\
\hline & 288.2538 & 0.0001 & 9.02 & 0.52 & unknown & - & - & - & - \\
\hline $\mathbf{M}$ & 402.3575 & 0.0001 & 6.97 & 0.28 & unknown & - & - & - & - \\
\hline
\end{tabular}


Fraction 2 was analysed in the same way, and compounds observed in the crude extract were examined in this fraction (Figure 7b). As in the crude extract, the compound $\mathrm{F}$ was the most abundant. Peaks B, D and E were observed in fraction 2 but only in very low abundances: $0.05 \%, 0.06 \%$ and $0.07 \%$ of compound F, respectively. The second most abundant compound (peak L, 24.4\% of compound F), was putatively annotated as 7,11-dihydroxy-16-oxo-12-spongien-17-al, furcellataepoxylactone or branacenal.

\section{Discussion}

Pinnatoxins are classified as "fast-acting toxins" and studies have demonstrated their acute toxicity to mice by intraperitoneal i.p. injection [2-4]. More specifically, the $\mathrm{LD}_{50}$ of PnTX-G by i.p. injection in mice was around $50 \mu \mathrm{g} \mathrm{kg}^{-1}$, with lethality always appearing within less than $30 \mathrm{~min}[5,16]$. PnTX-G also exhibited a high toxicity by the oral route, with an $\mathrm{LD}_{50}$ of $150 \mu \mathrm{g} \mathrm{kg}^{-1}$ by gavage, with lethalities appearing within 25-40 min [16]. Similar results were found with a crude extract of a peridinoid dinoflagellate producer of PnTXs: the toxicity to mice was high both by i.p. injection $\left(1.33 \mathrm{mg} \mathrm{kg}^{-1}\right)$ and by gavage $\left(2.33 \mathrm{mg} \mathrm{kg}^{-1}\right)$ [7]. The similarity of the $\mathrm{LD}_{50}$ s determined for these two routes of administration is quite unusual among cyclic imines. Indeed, it has been reported that gymnodimine was eight times less toxic by gavage than by i.p. injection, and desmethyl spirolide $\mathrm{C}$ was 18 times less toxic [22]. Therefore, contrary to the other cyclic imines, PnTX-G is likely to have a high oral bioavailability and to be easily absorbed through the GI tract.

In the present study, no inhibition of cell viability was observed with PnTX-G on the Neuro2A and Caco- 2 cell lines exposed to concentrations as high as $32 \mathrm{ng} \mathrm{mL}^{-1}$ as well as on $\mathrm{KB}$ cells exposed to up to $400 \mathrm{ng} \mathrm{mL}^{-1}$, even after $72 \mathrm{~h}$ of exposure. PnTX-A, -E and $-\mathrm{F}$ have been shown to block neuromuscular transmission through the inhibition of nicotinic acetylcholine receptors subtypes [19,20]. These receptors also are the target of PnTX-G [11]. This mechanism of action seemed to be strongly related to the spiro-imine subunit [19]. In our study, no inhibition of cell viability was observed with PnTX-G on the different cell lines, which may suggest the absence of PnTX-sensitive nicotinic acetylcholine receptors in these in vitro models.

The comparison of the axenic and non-axenic profiles led to the identification of PnTX-G in both cultures. The fact that V. rugosum produces PnTX-G also in axenic conditions, and at levels similar to non-axenic cultures, corroborates that PnTX-G is produced de novo by the alga and not by bacterial symbionts or fungal contamination present. Several other compounds were also identified in both axenic and non-axenic cultures, including the compound with a $m / z$ of $402.2281\left([\mathrm{M}+\mathrm{H}]^{+}\right)$. PnTX-G was exclusively concentrated in fraction 3, which was the second-most potent in terms of cytotoxicity (Table 3). As PnTX-G exhibited no activity on the different models, it could be concluded that other compounds were present and responsible for the toxicity. The compound with the $m / z$-value $402.2281\left([\mathrm{M}+\mathrm{H}]^{+}\right)$as well as some unidentified compounds previously discussed could also be detected in this fraction and may be responsible for all or part of the cytotoxicity exhibited by fraction 3 (see also below).

Fraction 2 was shown to be the most potent fraction to both Neuro2A and KB cells. This fraction was also the most potent in arresting the cell cycle of undifferentiated Caco- 2 cells in the G1/S phase. Occurring at lower concentrations, the cell cycle arrest appears to be the primary mechanism of 
toxicity. The increase in $\gamma \mathrm{H} 2 \mathrm{AX}$ immunofluorescence appears at higher concentrations, and may either indicate genotoxicity, or an increase in the number of apoptotic cells. The chemical profile of fraction 2 suggested the presence of compounds with a mass-to-charge ratio of $\mathrm{m} / \mathrm{z} \quad 402.2281$ $\left([\mathrm{M}+\mathrm{H}]^{+}\right)$and with a molecular formula putatively corresponding to three compounds in the MarinLit ${ }^{\mathrm{TM}}$ database: nakijiquinone $\mathrm{A}$, stachybotrin $\mathrm{A}$ or $\mathrm{N}$-carboxy-methyl-smenospongine. Nakijiquinone A and $\mathrm{N}$-carboxy-methyl-smenospongine both are sesquiterpenoid amino-quinones [23,24], whereas stachybotrin is an aromatic alkaloid [25]. Interestingly, those three classes of compounds are known to exhibit biological activities, especially cytotoxicity, albeit at rather high concentration. Even if the cytotoxicity is not particularly high $\left(\mu \mathrm{g} \mathrm{mL}^{-1}\right.$-range), the concentration of this compound appears rather high, since a 100-fold higher area was measured for peak F (Table 4) compared to PnTX-G (in the absence of calibration, standards peak areas are indicative of concentration of a compound). Nakijiquinones, isolated from Okinawan marine sponges, exhibited various activities as cytotoxicity against L-1210 murine leukemia and KB cells or weak inhibition of the Her-2/Neu tyrosine kinase receptor [26,27]. Smenospongine, the main representative of this compound group, had also been isolated from marine sponges and induced the differentiation of the leukemia cell line K562 into normal cells [28] and the inhibition of the growth of 39 human solid tumors [29]. Smenospongine and derivatives also induced a G1 arrest in the K562 cells, and apoptosis of other leukemia cell lines HL60 and U937 [30]. Stachybotrin A had initially been isolated from the marine fungus Stachybotris sp. Antifungal and antimicrobial activities were identified, as well as cytotoxicity on the epithelial adenocarcinoma A-549 cell line, the breast adenocarcinoma MCF-7 cell line and the colon adenocarcinoma HT-29 cell line [25]. Thus, any of these three compounds could potentially be responsible for the cytotoxicity of the fraction F2 of the V. rugosum extract. However, the MarinLit ${ }^{\mathrm{TM}}$ database only constitutes a collection of marine natural products while many new marine natural products are being discovered each year [31]. Further in-depth literature screening and eventually full purification of the compound will be necessary for full structure elucidation.

\section{Experimental Section}

\subsection{Reagents}

Methanol $(\mathrm{MeOH})$, acetone, acetonitrile and dichloromethane (DCM) were obtained as HPLC grade solvents from JT Baker and Sigma Aldrich. Hexane, formic acid (puriss quality) and ammonium formate (purity for MS) were obtained from Sigma-Aldrich. Milli-Q water for HPLC was produced in-house using a Milli-Q integral 3 system (Millipore). Pinnatoxin G (PnTX-G) was obtained from the National Research Council of Canada.

\subsection{Vulcanodinium rugosum Growth Conditions}

Vulcanodinium rugosum (IFR-VRU-01I) was grown during 83 days in flat-bottomed glass flask (10 L) of L1-medium [32]. The strain was maintained at $18{ }^{\circ} \mathrm{C}$, with a photon flux density at $200 \mu \mathrm{mol} \mathrm{m} \mathrm{m}^{-2} \mathrm{~s}^{-1}$ and a photoperiod of $16 \mathrm{~h}$ of light and $8 \mathrm{~h}$ of dark. Sea water (38 psu) was collected from the Mediterranean Sea, filtered and used for making up culture media. Cells were collected by centrifugation $\left(3500 \mathrm{~g}, 20 \mathrm{~min}, 4^{\circ} \mathrm{C}\right)$. 
Axenic cultures were obtained by using antibiotic-antimycotic treatment for $72 \mathrm{~h}$ using $10 \mathrm{ml} \mathrm{L}^{-1}$ penicillin-streptomycin-amphotericin solution (Gibco) containing 10,000 units penicillin and $10,000 \mu \mathrm{g} \mathrm{mL}^{-1}$ streptomycin sulfate and $25 \mu \mathrm{g} \mathrm{mL}^{-1}$ amphotericin B as Fungizone ${ }^{\circledR}$ in $0.85 \%$ saline, followed by transfer to fresh medium.

\subsection{Extraction, Purification and Fractionation of a Crude Extract of V. rugosum}

Three successive extractions of wet algal pellet $(6.3 \mathrm{~g})$ were carried out using $100 \% \mathrm{MeOH}$ $(20 \mathrm{~mL})$, followed by centrifugation $\left(2500 \mathrm{~g}, 10 \mathrm{~min}, 4{ }^{\circ} \mathrm{C}\right)$. The supernatants were pooled and dried by rotary evaporation, leading to the crude extract (Figure 8). A first purification step was carried out on the crude extract by liquid-liquid partitioning using DCM: distilled water (v/v, 2:1). The DCM phase $(300 \mathrm{~mL})$ was rinsed twice with aqueous $\mathrm{NaCl} 0.1 \mathrm{M}(150 \mathrm{~mL})$ and centrifugation $(2500 \times \mathrm{g}, 10 \mathrm{~min}$, $4{ }^{\circ} \mathrm{C}$ ). The supernatants were pooled and dried by rotary evaporation, leading to the DCM fraction. A second purification step was carried out on the DCM fraction by liquid-liquid partitioning using aqueous $\mathrm{MeOH} 70 \%$ (aqueous $\mathrm{MeOH}$ ) and hexane in proportions 2/1. The aqueous $\mathrm{MeOH}$ phase $(150 \mathrm{~mL})$ was rinsed twice with hexane $(50 \mathrm{~mL})$, followed by centrifugation $\left(2500 \mathrm{~g}, 10 \mathrm{~min}, 4^{\circ} \mathrm{C}\right)$. The supernatants were pooled and dried by rotary evaporation, leading to the aqueous $\mathrm{MeOH}$ fraction. A solid-phase extraction (SPE) was then carried out for fractionation of the aqueous $\mathrm{MeOH}$ fraction. SPE cartridges were silica-based (SPE UPTI-CLEAN SI-S 500/3, Interchrom). The extractions were carried out using five elution solvents: DCM 100\%, DCM/Acetone (85:15), DCM/Acetone (50:50), DCM/MeOH (80:20) and MeOH 100\%.

Figure 8. Schematic of the V. rugosum pellet purification procedure.

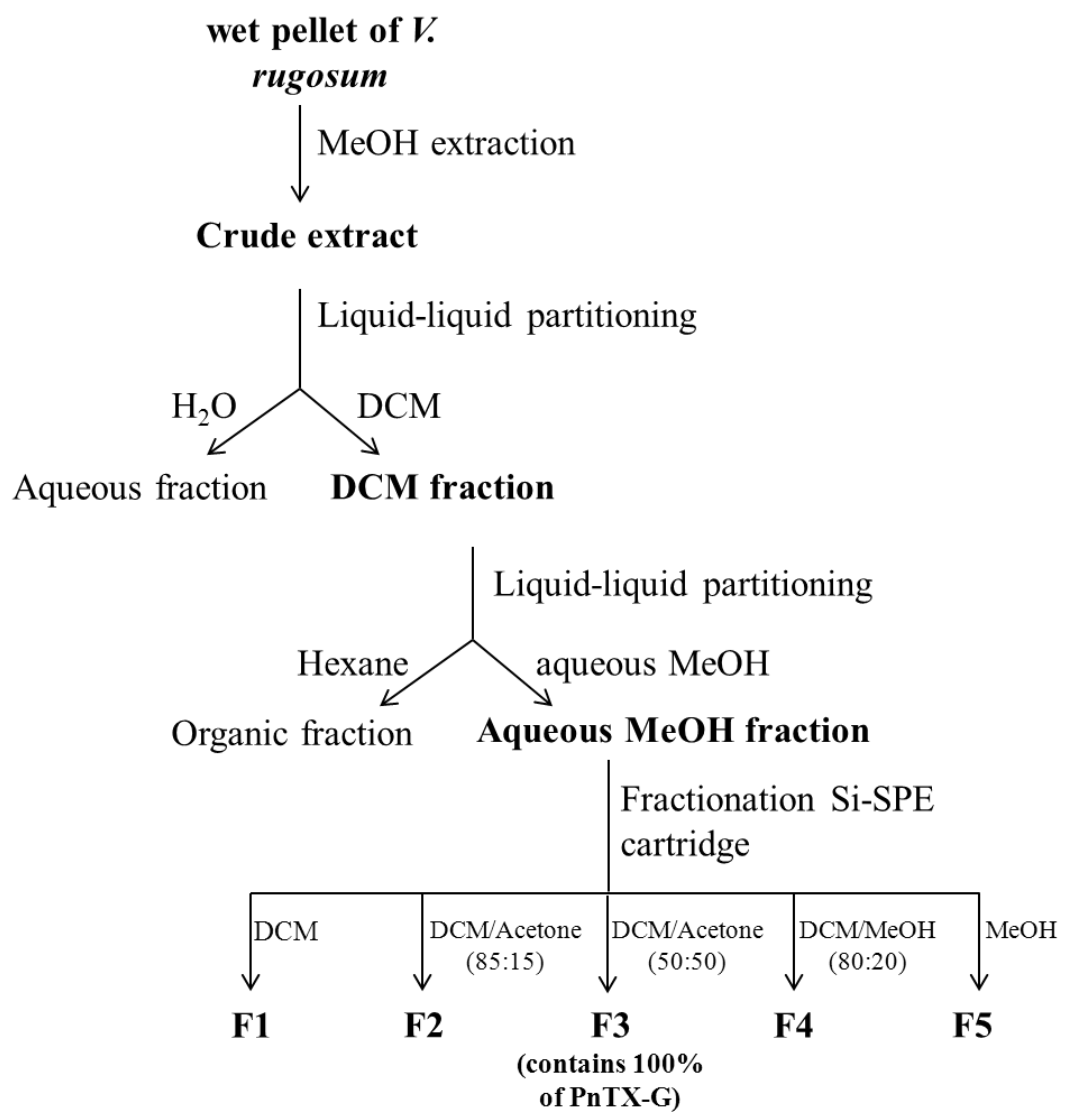


For analysis of an axenic culture of V.rugosum, $200 \mathrm{~mL}$ of batch culture were sacrificed 2 weeks after axenisation of the main culture. Cells were collected using both glass beads and a scraper, with subsequent centrifugation of the wet biomass. The cell pellet $(276 \mathrm{mg})$ was extracted in triplicate with $\mathrm{MeOH}(5 \mathrm{~mL}$ each) and taken up in $1 \mathrm{~mL} \mathrm{MeOH}$ prior to further dilutions. Dilutions of this solution were analysed by triple-stage quadrupole analysis for quantitation of PnTX-G and by quadrupole/time-of-flight mass spectrometry for metabolomic assessment of the algal contents.

\subsection{Quantification of PnTX-G Using a Triple Stage Quadrupole Mass Spectrometer}

Analysis of pinnatoxins was performed on a UFLC (model Nexera, Shimadzu) coupled to a triple-quadrupole mass spectrometer (5500Qtrap, AB Sciex). Chromatography was performed on a Hyperclone MOS C8 column $(50 \times 2.0 \mathrm{~mm}, 3 \mu \mathrm{m})$, with a C8 guard column $(4 \times 2.0 \mathrm{~mm}, 3 \mu \mathrm{m}$, Phenomenex). A binary mobile phase was used, phase A (100\% aqueous) and phase B (95\% aqueous acetonitrile), both containing $2 \mathrm{mM}$ ammonium formate and $50 \mathrm{mM}$ formic acid. The flow rate was $0.2 \mathrm{~mL} \mathrm{~min}^{-1}$ and injection volume was $5 \mu \mathrm{L}$. The column and sample temperatures were $25{ }^{\circ} \mathrm{C}$ and $4{ }^{\circ} \mathrm{C}$, respectively. A gradient elution was employed, starting with $30 \% \mathrm{~B}$, rising to $95 \% \mathrm{~B}$ over $2.5 \mathrm{~min}$, held for $5 \mathrm{~min}$, then decreased to $30 \% \mathrm{~B}$ in $0.1 \mathrm{~min}$ and held for $2.5 \mathrm{~min}$ to equilibrate the system.

The LC-MS/MS system was used in positive ionization and multiple reaction monitoring (MRM) mode, with the following three transitions per compound: PnTX-G $m / z$ 694.4 $\rightarrow 676.4,694.4 \rightarrow 458.3$ and $694.4 \rightarrow 164.1$; PnTX-A $m / z \quad 712.4 \rightarrow 694.4,712.4 \rightarrow 458.3$ and $712.4 \rightarrow 164.1$, PnTX-B and C, $\mathrm{m} / \mathrm{z} \quad 741.4 \rightarrow 723.5, \quad 741.4 \rightarrow 458.3$ and $741.4 \rightarrow 164.1$; PnTX-D, $m / z \quad 782.4 \rightarrow 764.4 \quad 782.4 \rightarrow 488.3$ and 782.4 $\rightarrow$ 164.1; PnTX-E, $m / z \quad 784.4 \rightarrow 764.4 \quad 784.4 \rightarrow 488.3$ and $784.4 \rightarrow 164.1$; PnTX F, $\mathrm{m} / \mathrm{z} \quad 766.4 \rightarrow 738.4,766.4 \rightarrow 488.3$ and $766.4 \rightarrow 164.1$; pteriatoxins $\mathrm{A}, \mathrm{B}$ and $\mathrm{C} \mathrm{m} / \mathrm{z} \quad 831.5 \rightarrow 787.5$, $831.5 \rightarrow 458.3$ and $831.5 \rightarrow 164.1$. The most intense transition, giving the product ion $\mathrm{m} / \mathrm{z} 164.1$, was used to quantify toxins. All toxins were quantified against the PnTX-G standard from NRC, assuming that all analogues had the same response factor as PnTX-G.

The ESI interface was operated using the following parameters: curtain gas 30 psi, temperature: $650{ }^{\circ} \mathrm{C}$, gas $150 \mathrm{psi}$; gas $260 \mathrm{psi}$, ion spray voltage $5500 \mathrm{~V}$. For detection, parameters were as follows: the declustering potential was $30 \mathrm{~V}$ and the entrance potential $10 \mathrm{~V}$. Three collision energies were applied (53,59 and $67 \mathrm{eV}$ ) with collision cell exit potentials of 10, 6 and $10 \mathrm{~V}$ for transitions 1,2 and 3 of each compound, respectively.

The limit of detection (LOD) was determined from the signal-to-noise ratio of the lowest standard injected after injection of 20 samples, using automated calculation in the Analyst 1.5.1 software of Applied Biosystems: This algorithm calculates the LOD as the sample giving a signal height 3 times the standard deviation of the noise. The LOD ( $5 \mu \mathrm{L}$ injected) was $250 \mathrm{fg}$ on the column.

\subsection{Growth Conditions of the Different Cell Lines}

Different cell lines were chosen for this study: Neuro2A, undifferentiated and differentiated Caco-2 and $\mathrm{KB}$ cells. Neuro2A and Caco-2 cell lines derived from the nervous system and intestine, respectively, organs that are known as targets for some phycotoxins. These two cell lines, as well as 
KB cells, have been previously used to study the detection of algal toxins in shellfish extracts [33-36]. Furthermore, KB cells are a rugged cell line frequently used in our laboratory.

Neuro2A cells: The mouse Neuro2A neuroblastoma cell line (ATCC CCL-131, passages 11-50) was cultured in RPMI 1640-Glutamax containing $2 \mathrm{~g} \mathrm{~L}^{-1}$ glucose, and supplemented with $10 \%$ fetal calf serum (FCS), $1 \mathrm{mM}$ sodium pyruvate, $50 \mathrm{U} \mathrm{mL}^{-1}$ penicillin and $50 \mu \mathrm{g} \mathrm{mL}^{-1}$ streptomycin. The cell line was routinely grown in $75 \mathrm{~cm}^{2}$ flasks at $37{ }^{\circ} \mathrm{C}$ and $5 \% \mathrm{CO}_{2}$ and detached mechanically for sub-culturing.

Undifferentiated Caco-2 cells: The human Caco-2 colorectal adenocarcinoma cell line (ATCC HTB-37, passages 18-40) were cultured in MEM-Glutamax containing $1 \mathrm{~g} \mathrm{~L}^{-1}$ glucose and supplemented with $10 \% \mathrm{FCS}, 50 \mathrm{U} \mathrm{mL}^{-1}$ penicillin and $50 \mu \mathrm{g} \mathrm{mL}^{-1}$ streptomycin and $1 \%$ non-essential amino acids. The cell line was routinely grown in $75 \mathrm{~cm}^{2}$ flasks at $37{ }^{\circ} \mathrm{C}$ and $5 \% \mathrm{CO}_{2}$ and passaged twice a week by trypsinization prior to cell centrifugation ( $5 \mathrm{~min}, 136 \mathrm{~g})$.

Differentiated Caco-2 cells: To obtain differentiated Caco- 2 cells, 60,000 cells $\mathrm{cm}^{2}$ were seeded in 48 wells plates with $200 \mu \mathrm{L}$ per well of medium as described previously. Medium was renewed each 2-3 days. Caco- 2 cells reached confluence after 3 days and were differentiated 21 days after.

$\mathrm{KB}$ cells: The $\mathrm{KB}$ cells were maintained at $37{ }^{\circ} \mathrm{C}$ in a $95 \%$ air, $5 \% \mathrm{CO}_{2}$ atmosphere in Eagle's basal medium (Sigma-Aldrich) supplemented with $5 \%(\mathrm{v} / \mathrm{v})$ of FCS and a mix leading to final concentrations of $400 \mathrm{nM}$ L-glutamine, $20 \mathrm{U} \mathrm{mL}^{-1}$ penicillin-G and $100 \mu \mathrm{g} \mathrm{mL}^{-1}$ streptomycin (Sigma-Aldrich). Cells were grown in culture flasks (Dutscher) until cell confluence.

\subsection{Cytotoxicity Assays}

Neuro2A and Caco-2 cells: Except for differentiated Caco-2, cells were seeded in 96-well plates at a density of 50,000 cells $100 \mu \mathrm{L}^{-1}$ well ${ }^{-1}$ (for undifferentiated Caco-2) and 20,000 cells $100 \mu \mathrm{L}^{-1}$ well $^{-1}$ (for Neuro2A) $24 \mathrm{~h}$ prior to treatment. After removing the medium, cells were exposed in duplicate to the compound in serum free-medium $\left(100 \mu \mathrm{L}\right.$ well $\left.{ }^{-1}\right)$ for 24 or $48 \mathrm{~h}$, as indicated. The template of each 96 well plate was designed by omitting marginal rows and columns; six wells were used for the control and six wells for the vehicle control. The vehicle control (VeC) contained 5\% methanol, the highest concentration of methanol used and which was previously shown to induce no cytotoxicity [34]. Differentiated Caco- 2 cells were treated in 48 wells plates with serum free-medium $\left(200 \mu \mathrm{L}\right.$ well $\left.{ }^{-1}\right)$ for $48 \mathrm{~h}$.

KB cells: Cells were rinsed with Dulbecco's phosphate buffered saline (Sigma-Aldrich), removed from culture flasks by treatment with trypsin (Sigma-Aldrich), enumerated and diluted with fresh medium. Inoculation of microplates was different for observations at 24,48 and $72 \mathrm{~h}$ or to the single observation at $72 \mathrm{~h}$. For the study with different time points, cells were seeded at a density of 70,000 cells $100 \mu \mathrm{L}^{-1}$ well ${ }^{-1}$ and plates were incubated for $72 \mathrm{~h}$. Medium culture was then removed from each well and replaced by $50 \mu \mathrm{L}$ of fresh medium. For the single observation, cells were seeded at a density of 200,000 cells $50 \mu \mathrm{L}^{-1}$ well ${ }^{-1}$ and plates were incubated $48 \mathrm{~h}$. The template of each 96 well plate was designed by omitting marginal rows and columns. For the two types of experiments, test samples were prepared in $\mathrm{MeOH}$, diluted 10-fold in culture medium and $50 \mu \mathrm{L}$ of this diluted test solution were added to each well, reaching a final concentration of 5\% methanol. Concentrations were 
tested in triplicate, and experiments were carried out in duplicate. Culture medium with $5 \% \mathrm{MeOH}$ was used as negative control.

\subsection{Assessment of the Cell Viability}

Cytotoxicity testing for Neuro2A and undifferentiated Caco-2 cells followed the conditions set up in Sérandour et al. (2011) [34]. Only a short duration of exposure was selected for Neuro2A while exposure on Caco-2 and KB cells was increased up to $72 \mathrm{~h}$ due to the longer cell doubling time of these two models ( $20 \mathrm{~h}$ and $48 \mathrm{~h}$, respectively).

For Neuro2A and Caco-2 cells, the cytotoxicity was measured using the 3-(4,5-dimethylthiazol-2yl)-2,5-diphenyltetrazolium bromide (MTT) assay. After treatment, the medium was replaced by a FCS-free medium containing $0.5 \mathrm{mg} \mathrm{mL}^{-1} \mathrm{MTT}$ (Sigma) for $2 \mathrm{~h}$ at $37{ }^{\circ} \mathrm{C}$. The medium was discarded prior to the addition of $0.1 \mathrm{~N} \mathrm{HCl}$-acidified isopropanol to dissolve the formazan. The absorbance was read at $570 \mathrm{~nm}$ and was expressed as the percentage of mean absorbance $(N=2)$ in $\mathrm{VeC}$ (100\% viability).

For KB cells, after 24,48 or $72 \mathrm{~h}$ of incubation at $37{ }^{\circ} \mathrm{C}, 50 \mu \mathrm{L}$ of a mix of solution 1 and 2 of a kit based on the 2,3-bis(2-methoxy-4-nitro-5-sulfophenyl)-5-[(phenylamino)carbonyl]-2 $\mathrm{H}$-tetrazolium (XTT-based kit, Roche) were added to each well, followed by an incubation of $4 \mathrm{~h}$ at $37{ }^{\circ} \mathrm{C}$. Plates were gently shaken and read at $405 \mathrm{~nm}$ and $630 \mathrm{~nm}$ with a microplate reader (EL800, Bio-Tek). The absorption values for each extract were averaged and the averages were then expressed as a percentage, relative to the solvent control.

\section{8. $I C_{50}$ Determination}

Inhibition curves for Neuro2A and Caco-2 cells were modeled using a nonlinear regression analysis (GraphPad Prism, version 5.0c, San Diego, CA, USA). Concentrations at which cell growth was inhibited to $50 \%\left(\mathrm{IC}_{50} \mathrm{~S}\right)$ and $95 \%$ confidence intervals were also calculated with the same model. The model did not fit with the curve of $\mathrm{KB}$ cells viability, so $\mathrm{IC}_{50} \mathrm{~s}$ were calculated using linear interpolation of the two points surrounding $50 \%$ inhibition.

\subsection{DNA Damage and Cell Cycle Progression Measurements}

Following $24 \mathrm{~h}$ treatment, undifferentiated Caco-2 cells in 96-well plates were fixed with $4 \%$ formaldehyde and permeabilised with $0.2 \%$ Triton X-100. After 3 washes with PBS-tween 20 $(0.05 \%)$, cells were incubated overnight with an anti- $\gamma \mathrm{H} 2 \mathrm{AX}$ mouse monoclonal antibody (Thermo MA1-2022; 1:1500), or a rabbit anti Ki-67 (Abcam ab15,580; 1:1000). Histone H2AX is phosphorylated into $\gamma \mathrm{H} 2 \mathrm{AX}$ after DNA damage and Ki-67 is a marker of cell proliferation. Cells were then washed 3 times with PBS-tween and incubated with Dylight 550-conjugated goat anti-mouse or Dylight 488-conjugated goat anti-rabbit secondary antibodies (1:1000) for $45 \mathrm{~min}$. Nuclei were stained with DAPI. The mean average fluorescence intensity was quantified using an Arrayscan VTi high content screening microscope using the Target Activation algorithm. The average nuclear intensity was calculated from ten fields per well, three wells per condition. Two independent experimentations were carried out. 


\subsection{Dereplication Study Using a Quadrupole-Time-of-Flight Hybrid Mass Spectrometer}

As the cytotoxicity study suggested the presence of cytotoxic compounds different from PnTX-G, an in-depth study was undertaken using high resolution mass spectrometry (HRMS).

Aliquots $(5 \mu \mathrm{L})$ of each sample were separated on a Kinetex $1.7 \mu \mathrm{m} \mathrm{C18} 100 \AA$ (Phenomenex) column $(150 \times 2.1 \mathrm{~mm})$ maintained at $40{ }^{\circ} \mathrm{C}$, using an Agilent 1290 Infinity LC system with a gradient mobile phase $\left(0.5 \mathrm{~mL} \mathrm{~min}^{-1}\right)$ comprising $0.1 \%$ aqueous acetic acid (A) and acetonitrile containing $0.1 \%$ acetic acid (B). The gradient was as follows: $5 \% \mathrm{~B}$ from 0 to $2.4 \mathrm{~min}$, raise to $25 \% \mathrm{~B}$ from 2.4 to $4.5 \mathrm{~min}$, then raise to $30 \% \mathrm{~B}$ from 4.5 to $11 \mathrm{~min}$, finally raise to $100 \% \mathrm{~B}$ from 11 to $14 \mathrm{~min}$ and maintain until $16.5 \mathrm{~min}$, subsequently decrease to $5 \% \mathrm{~B}$ until $20 \mathrm{~min}$ and maintain at $5 \% \mathrm{~B}$ until $25 \mathrm{~min}$. The eluent was directly introduced into the mass spectrometer by electrospray. Mass spectrometry was performed on a 6540 UHD Q-TOF mass spectrometer (Agilent Technologies, Waldbronn, Germany), operating in positive ion mode. The capillary voltage, fragmentor voltage and skimmer were set to 3900,150 and $60 \mathrm{~V}$, respectively. The sheath gas was at $350{ }^{\circ} \mathrm{C}\left(12 \mathrm{~mL} \mathrm{~min}^{-1}\right)$ and the drying gas at $175{ }^{\circ} \mathrm{C}\left(5 \mathrm{~mL} \mathrm{~min}^{-1}\right)$ and nebulizer 43 psi. Nitrogen was used as collision gas. Mass spectra were acquired in full scan analysis over an $\mathrm{m} / \mathrm{z}$ range of 50-1700 using extended dynamic range and storage in centroid mode. To maintain mass accuracy throughout the run, a reference mass solution containing reference ions 121.0508 and 922.0097 was used in the positive ionization mode. The correction of mass axis using these reference ions typically results in a mass accuracy of $1 \mathrm{ppm}$ in full scan mode and $2 \mathrm{ppm}$ in fragmentation mode. Data station operating software was MassHunter Workstation Software (versionB.05).

Metabolomic fingerprints were deconvoluted to allow the conversion of the three-dimensional raw data $(\mathrm{m} / \mathrm{z}$, retention time, ion current) to time- and mass-aligned chromatographic peaks with associated peak areas. Data were processed using MassHunter Qualitative Analysis software (Agilent Technologies) where compounds were extracted from the raw data using the Molecular Feature Extractor (MFE) algorithm.

Molecular feature extractor. The MFE algorithm is a compound finding technique that locates individual sample components (molecular features), even when chromatograms are complex and compounds are not well resolved chromatographically. MFE locates ions that are covariant (rise and fall together in abundance) and the algorithm uses the accuracy of the mass measurements to group related ions - related by charge-state envelope, isotopic distribution, and/or the presence of adducts and dimers. It assigns multiple species (ions) that are related to the same neutral molecule (for example, ions representing multiple charge states or adducts of the same neutral molecule) to a single compound that is referred to as a feature. Using this approach, the MFE algorithm can locate multiple compounds at any given retention time, i.e., also in a single peak [37].

The result is a compound table with associated chromatograms and pure spectra, ready for further analysis. Subsequently, samples were processed using MassProfiler software (Agilent Technologies) and compound identification was performed using an in-house database and the MarinLit ${ }^{\mathrm{TM}}$ database.

To ensure reproducibility and precision, analyses were carried out in triplicate. 


\section{Conclusions}

PnTX-G is a marine toxin inducing strong neurological symptoms in mice but this study revealed that it is not a potent cytotoxic compound, using the Neuro2A, Caco-2and KB cell lines. However, a crude extract of a culture of $V$. rugosum induced a reduction of the cell viability of those three different cell lines, as well as cell cycle arrest accompanied by DNA damage. A crude extract was fractionated and the fraction exhibiting the more potent in vitro activity did not contain PnTX-G. The dereplication of the crude extract and fraction revealed that these activities could be induced by compounds such as nakijiquinone a, $\mathrm{N}$-carboxy-methyl-smenospongine or stachybotrin $\mathrm{A}$, which have previously been reported to be cytotoxic. Further investigations will be necessary to identify and purify compounds responsible for the activity of $V$. rugosum crude extracts and fractions.

\section{Acknowledgements}

We acknowledge the collaboration of Paul McNabb and Andrew I. Selwood (both Cawthron Institute, New Zealand) and Michael A. Quilliam and Pearse McCarron (both Institute of Marine Biosciences, National Research Council Canada) for the provision of a well characterized reference solution for PnTX-G. The authors thank Thomas Glauner and Bernhard Wüst (both Agilent) for their collaboration on high resolution mass spectrometry. We gratefully thank Rachelle Lanceleur and Pierre-Jean Ferron (Anses, Fougères) for technical assistance. We also thank the technical staff of the Laboratoire Phycotoxines (Ifremer, Nantes) and the Laboratoire Ressources Environnement-Languedoc-Roussillon (Ifremer, Sète) for help in the selection of samples and initial analysis of samples from Ingril Lagoon. Informatic tools developed in the ChiMiMar project were used (Regional Council of the "Pays de la Loire", 2010-2013).

Funding for this work came from the following separate sources: (i) the COLNACOQ project funded by the Regional Council of the "Pays de la Loire" (2009-2013); (ii) the French Directorate General for Food (DGAL), through Programme 206, convention number 2011/203/2100482701 (2011-2012); iii) Ifremer through the DiALTOX and RISCAP projects funded by the French Ministry of Research and Higher Education through programme 148 (2009-2012).

\section{Conflicts of Interest}

The authors declare no conflict of interest.

\section{References}

1. Zheng, S.; Huang, F.; Chen, S.; Tan, X.; Zuo, J.; Peng, J.; Xie, R. The isolation and bioactivities of pinnatoxin. Chin. J. Mar. Drugs 1990, 9, 33-35.

2. Uemura, D.; Chou, T.; Haino, T.; Nagatsu, A.; Fukuzawa, S.; Zheng, S.Z.; Chen, H.S. Pinnatoxin-A a toxic amphoteric macrocycle from the okinawan bivalve Pinna muricata. J. Am. Chem. Soc. 1995, 117, 1155-1156.

3. Chou, T.; Haino, T.; Kuramoto, M.; Uemura, D. Isolation and structure of pinnatoxin D, a new shellfish poison from the okinawan bivalve Pinna muricata. Tetrahedron Lett. 1996, 37, 4027-4030. 
4. Takada, N.; Umemura, N.; Suenaga, K.; Chou, T.; Nagatsu, A.; Haino, T.; Yamada, K.; Uemura, D. Pinnatoxins B and $\mathrm{C}$, the most toxic components in the pinnatoxin series from the okinawan bivalve Pinna muricata. Tetrahedron Lett. 2001, 42, 3491-3494.

5. Selwood, A.I.; Miles, C.O.; Wilkins, A.L.; van Ginkel, R.; Munday, R.; Rise, F.; McNabb, P. Isolation, structural determination and acute toxicity of pinnatoxins E, F and G. J. Agric. Food Chem. 2010, 58, 6532-6542.

6. Rundberget, T.; Aasen, J.A.B.; Selwood, A.I.; Miles, C.O. Pinnatoxins and spirolides in norwegian blue mussels and seawater. Toxicon 2011, 58, 700-711.

7. Rhodes, L.; Smith, K.; Selwood, A.; McNabb, P.; van Ginkel, R.; Holland, P.; Munday, R. Production of pinnatoxins by a peridinoid dinoflagellate isolated from Northland, New Zealand. Harmful Algae 2010, 9, 384-389.

8. Smith, K.F.; Rhodes, L.L.; Suda, S.; Selwood, A.I. A dinoflagellate producer of pinnatoxin G, isolated from sub-tropical Japanese waters. Harmful Algae 2011, 10, 702-705.

9. Rhodes, L.; Smith, K.; Selwood, A.; McNabb, P.; Molenaar, S.; Munday, R.; Wilkinson, C.; Hallegraeff, G. Production of pinnatoxins E, F and G by scrippsielloid dinoflagellates isolated from Franklin Harbour, South Australia. N. Z. J. Mar. Freshw. Res. 2011, 45, 703-709.

10. Nézan, E.; Chomerat, N. Vulcanodinium rugosum gen. Nov., sp. Nov. (dinophyceae): A new marine dinoflagellate from the French mediterranean coast. Cryptogam. Algol. 2011, 32, 3-18.

11. Hess, P.; Abadie, E.; Hervé, F.; Berteaux, T.; Séchet, V.; Aráoz, R.; Molgó, J.; Zakarian, A.; Sibat, M.; Rundberget, T.; et al. Pinnatoxin $\mathrm{G}$ is responsible for atypical toxicity in mussels (Mytilus galloprovincialis) and clams (Venerupis decussata) from Ingril, a French mediterranean lagoon. Toxicon 2013, doi:10.1016/j.toxicon.2013.05.001.

12. Rhodes, L.; Smith, K.; Selwood, A.; McNabb, P.; Munday, R.; Suda, S.; Molenaar, S.; Hallegraeff, G. Dinoflagellate Vulcanodinium rugosum identified as the causative organism of pinnatoxins in Australia, New Zealand and Japan. Phycologia 2011, 50, 624-628.

13. McCarron, P.; Rourke, W.A.; Hardstaff, W.; Pooley, B.; Quilliam, M.A. Identification of pinnatoxins and discovery of their fatty acid ester metabolites in mussels (Mytilus edulis) from eastern canada. J. Agric. Food Chem. 2012, 60, 1437-1446.

14. European Food Safety Authority. Opinion of the scientific panel on contaminants in the food chain on a request from the european commission on marine biotoxins in shellfish-cyclic imines (spirolides, gymnodimines, pinnatoxins and pteriatoxins). Eur. Food Saf. Auth. J. 2010, 8, 1628.

15. Cembella, A.; Krock, B. Cyclic Imine Toxins: Chemistry, Biogeography, Biosynthesis, and Pharmacology. In Seafood and Freshwater Toxins-Pharmacology, Physiology and Detection, 2nd ed.; Botana, L.M., Ed.; CRC Press Taylor \& Francis Group: Boca Raton, FL, USA, 2008; p. 941.

16. Munday, R.; Selwood, A.I.; Rhodes, L. Acute toxicity of pinnatoxins E, F and G to mice. Toxicon 2012, 60, 995-999.

17. Jackson, J.J.; Stivala, C.E.; Iorga, B.I.; Molgo, J.; Zakarian, A. Stability of cyclic imine toxins: Interconversion of pinnatoxin amino ketone and pinnatoxin a in aqueous media. J. Org. Chem. 2012, 77, 10435-10440.

18. Kuramoto, M.; Arimoto, H.; Uemura, D. Bioactive alkaloids from the sea: A review. Mar. Drugs 2004, 2, 39-54. 
19. Araoz, R.; Servent, D.; Molgo, J.; Iorga, B.I.; Fruchart-Gaillard, C.; Benoit, E.; Gu, Z.; Stivala, C.; Zakarian, A. Total synthesis of pinnatoxins A and $\mathrm{G}$ and revision of the mode of action of pinnatoxin A. J. Am. Chem. Soc. 2011, 133, 10499-10511.

20. Hellyer, S.D.; Selwood, A.I.; Rhodes, L.; Kerr, D.S. Marine algal pinnatoxins E and F cause neuromuscular block in an in vitro hemidiaphragm preparation. Toxicon 2011, 58, 693-699.

21. Marine Literature Database, Version 13.5; Marine Chemistry Group, Department of Chemistry, University of Canterbury: Christchurch, New Zealand, 2007.

22. Munday, R. Toxicology of the Pectenotoxins. In Seafood and Freshwater Toxins-Pharmacology, Physiology and Detection, 2nd ed.; Botana, L.M., Ed.; CRC Press Taylor\&Francis Group: Boca Raton, FL, USA, 2008; pp. 371-380.

23. Kondracki, M.L.; Guyot, M. Smenospongine: A cytotoxic and antimicrobial aminoquinone isolated from Smenospongia sp. Tetrahedron Lett. 1987, 28, 5815-5818.

24. Shigemori, H.; Madono, T.; Sasaki, T.; Mikami, Y.; Kobayashi, J. Nakijiquinones A and B, new antifungal sesquiterpenoid quinones with an amino acid residue from an Okinawan marine sponge. Tetrahedron 1994, 50, 8347-8354.

25. Xu, X.; de Guzman, F.S.; Gloer, J.B. Stachybotrins A and B: Novel bioactive metabolites from a brackish water isolate of the fungus Stachybotrys sp. J. Org. Chem. 1992, 57, 6700-6703.

26. Stahl, P.; Kissau, L.; Mazitschek, R.; Huwe, A.; Furet, P.; Giannis, A.; Waldmann, H. Total synthesis and biological evaluation of the nakijiquinones. J. Am. Chem. Soc. 2001, 123, 11586-11593.

27. Gordaliza, M. Cytotoxic terpene quinones from marine sponges. Mar. Drugs 2010, 8, 2849-2870.

28. Aoki, S.; Kong, D.; Matsui, K.; Rachmat, R.; Kobayashi, M. Sesquiterpene aminoquinones, from a marine sponge, induce erythroid differentiation in human chronic myelogenous leukemia, K562 cells. Chem. Pharm. Bull. 2004, 52, 935-937.

29. Kong, D.; Yamori, T.; Kobayashi, M.; Duan, H. Antiproliferative and antiangiogenic activities of smenospongine, a marine sponge sesquiterpene aminoquinone. Mar. Drugs 2011, 9, 154-161.

30. Kong, D.; Aoki, S.; Sowa, Y.; Sakai, T.; Kobayashi, M. Smenospongine, a sesquiterpene aminoquinone from a marine sponge, induces G1 arrest or apoptosis in different leukemia cells. Mar. Drugs 2008, 6, 480-488.

31. Mayer, A.M.S.; Rodríguez, A.D.; Berlinck, R.G.S.; Hamann, M.T. Marine pharmacology in 2005-2006: Marine compounds with anthelmintic, antibacterial, anticoagulant, antifungal, anti-inflammatory, antimalarial, antiprotozoal, antituberculosis, and antiviral activities; affecting the cardiovascular, immune and nervous systems, and other miscellaneous mechanisms of action. Biochim. Biophys. Acta 2009, 1790, 283-308.

32. Guillard, R.R.L.; Hargraves, P.E. Stichochrysis immobilis is a diatom, not a chrysophyte. Phycologia 1993, 32, 234-236.

33. Ledreux, A.; Sérandour, A.-L.; Morin, B.; Derick, S.; Lanceleur, R.; Hamlaoui, S.; Furger, C.; Biré, R.; Krys, S.; Fessard, V. Collaborative study for the detection of toxic compounds in shellfish extracts using cell-based assays. Part II: Application to shellfish extracts spiked with lipophilic marine toxins. Anal. Bioanal. Chem. 2012, 403, 1995-2007. 
34. Sérandour, A.L.; Ledreux, A.; Morin, B.; Derick, S.; Augier, E.; Lanceleur, R.; Hamlaoui, S.; Moukha, S.; Furger, C.; Bire, R.; et al. Collaborative study for the detection of toxic compounds in shellfish extracts using cell-based assays. Part I: Screening strategy and pre-validation study with lipophilic marine toxins. Anal. Bioanal. Chem. 2012, 403, 1983-1993.

35. Amzil, Z.; Pouchus, Y.F.; Le, B.J.; Roussakis, C.; Verbist, J.F.; Marcaillou-Lebaut, C.; Masselin, P. Short-time cytotoxicity of mussel extracts: A new bioassay for okadaic acid detection. Toxicon 1992, 30, 1419-1425.

36. Tubaro, A.; Florio, C.; Luxich, E.; Vertua, R.; Loggia, R.D.; Yasumoto, T. Suitability of the MTT-based cytotoxicity assay to detect okadaic acid contamination of mussels. Toxicon 1996, 34, 965-974.

37. Sana, T.R.; Roark, J.C.; Li, X.; Waddell, K.; Fischer, S.M. Molecular formula and metlin personal metabolite database matching applied to the identification of compounds generated by LC/TOF-MS. J. Biomol. Tech. 2008, 19, 258-266.

(C) 2013 by the authors; licensee MDPI, Basel, Switzerland. This article is an open access article distributed under the terms and conditions of the Creative Commons Attribution license (http://creativecommons.org/licenses/by/3.0/). 